\title{
BACTERIAL COMPOSITION OF BIOFILMS OF A LOCAL TIGERNUT DRINK PROCESSING UNIT IN YENAGOA, NIGERIA
}

\author{
Juliana Okwena Pondei* and Adenike Bosede Ariyo
}

Department of Microbiology, Federal University Otuoke, PMB 126, Yenagoa, Bayelsa State

*Corresponding Author Email: julipondei@gmail.com

\section{Cite this article:}

Juliana O.P., Adenike B.A. (2021), Bacterial Composition of Biofilms of a Local Tigernut Drink Processing Unit in Yenagoa, Nigeria. African Journal of Environment and Natural Science Research 4(2), 59-70. DOI: 10.52589/AJENSROVSSRKIU.

\section{Manuscript History}

Received: 24 April 2021

Accepted: 13 May 2021

Published: 19 May 2021

Copyright $\odot 2020$ The Author(s). This is an Open Access article distributed under the terms of Creative Commons AttributionNonCommercial-NoDerivatives 4.0 International (CC BY-NC-ND 4.0 ), which permits anyone to share, use, reproduce and redistribute in any medium, provided the original author and source are credited.
ABSTRACT: Microorganisms grow and form biofilms on surfaces of equipment employed in food processing. These biofilms are considered as the major sources of contamination in the food industry. The study determined the bacterial load and composition on surfaces of equipment and utensils employed in tigernut drink production, from a vendor with a production unit located in an open market in Yenagoa, Nigeria. Swabs were taken from different sampling points made of varying materialsthe grinding machine (metal), the collection bowls, water storage containers (thick plastic) and retail bottles (light plastic). These were analysed for total heterotrophic bacterial counts (THBC) and bacterial diversity using standard procedures. The THBC of water used in the drink production was also determined. The THBC of the sampling points ranged from $\log 3.28 \pm 0.06 \mathrm{cfu} / \mathrm{cm}^{2}$ to $\log 5.18 \pm 0.05 \mathrm{cfu} / \mathrm{cm}^{2}$, and $\log 5.13 \pm 0.07 \mathrm{cfu} / \mathrm{ml}$ for the water sample. The grinder and water recorded higher bacterial load with a statistically significant difference $(P<0.05)$. The retail bottles had the least bacterial count. Shigella spp. were the most isolated (27.451\%), then Salmonella spp. (21.568\%) and E. coli (15.686\%). Streptococcus spp., Staphylococcus spp. and Vibrio spp. were the least isolated $(11.765 \%$ each). Shigella and Salmonella species occurred at all sampling points but not on the retail bottles. E. coli was present in the water collection bowls and retail bottles while Streptococcus, Staphylococcus and Vibrio were found only in the retail bottles. On diversity, four bacterial genera $(39.216 \%)$ were isolated from the retail bottles, three (25.490\%) from the water storage containers and two (17.647\%) from the grinder and collection bowls. The microorganisms possibly had preference for attachment to the surfaces based on the material makeup and nutrient availability. Their occurrence and high numbers reflect the low level of hygiene employed prior to drink production. This could be of public health concern.

Keywords: Bacteria, Biofilms, Equipment, Tigernut Drink, Public Health. 


\section{INTRODUCTION}

The surfaces of equipment used in the production of food and beverages are usually contaminated by microorganisms during their processing and handling, despite the fact that cleaning and disinfection protocols are observed (Marouani-Gadri et al., 2010). These surface contaminating microorganisms - called biofilms - occur in food processing plants and storage tanks. Biofilms are complex systems made up of prokaryotic and/or eukaryotic microorganisms embedded in a three-dimensional extracellular matrix (made up of extracellular polymeric substances, EPS), attached to surfaces. Biofilms protect bacterial cells against environmental, chemical and mechanical stress such as desiccation, resistance to antibiotics and disinfectants, and the immune response in a host as well as in seasons of nutritional scarcity (Van Houdt \& Michiels, 2010; Karunakaran et al., 2011; Vert et al., 2012; Flemming et al., 2016; Shakibaie, 2018).

Biofilm formation is of enormous importance (both positive and negative) in a range of disciplines and applications in biotechnology, in the environment and in medicine. A lot of reviews exist on the detailed formation and components of biofilms (Karunakaran et al., 2011; Marchand et al., 2012; Satpathy et al., 2016; Shakibaie, 2018). Microorganisms develop biofilms on various materials or utensils utilized in the food industry, which include stainless steel, polyethylene, wood, glass, polypropylene, rubber, etc. (Abdallah et al., 2014; Colagiorgi et al., 2017). The presence of these biofilms on surfaces of food processing plants places them as high-risk reservoirs of infectious and spoilage agents in the food industry. The result is an increase in post processing contamination leading to public health concerns (Van Houdt and Michiels, 2010; Galie et al., 2018). Moreover, biofilms in equipment and structures of food processing may cause corrosion, blockage of fluid systems and less heat transfer, resulting in economic losses (Chmielewski and Frank, 2003; Brooks and Flint, 2008; Tilahun et al., 2016).

Tigernut (Cyperus esculentus L.) is a perennial grass-like plant, having spheroid, pale yellow tubers with a cream kernel surrounded by a fibrous sheath. It occurs wild or cultivated in Europe, West Africa, South America, and Asia. Tigernuts are sweet and can be eaten raw, roasted, dried or processed as a drink. The flavoured tubers contain protein, minerals, vitamins, carbohydrate, sugars, oil and fiber (Balewu and Balewu, 2007; Suleiman et al., 2018).

In local tigernut drink production, the procedure involves simple processes of sorting and washing of the nuts before grinding and extraction of the juice (milk), and then bottling. The absence of an effective antimicrobial treatment, from obtaining the raw tubers to processing and consumption of the final product, means that pathogens could be introduced at any point (Sagoo et al., 2001). Microorganisms such as Escherichia coli, Bacillus subtilis, Staphylococcus aureus, Aspergillus flavus, Aspergillus niger, Fusarium solani, Saccharomyces cerevisiae, Saccharomyces fibuligera, Candida pseudotropicalis, Enterobacter cloacae, Enterococcus spp., Pseudomonas aeruginosa and Streptococcus spp. have been found to be associated with tigernuts (Onovo and Ogaraku, 2007; Hubert et al., 2011; Gambo and Da'u, 2014). Fresh and dry nuts were seen to harbour Aspergillus niger, Aspergillus flavus, Aspergillus terreus and Penicillium italicum, and in dry nuts, Penicillium citrinum and Aspergillus fumigatus were isolated (Chukwu et al., 2013; Gambo and Da'u, 2014; Agbaje et al., 2015; Roselló-Soto, 2019). Several parasites, particularly Cryptosporidium parvum, were found in raw tubers (Ayeh-Kumi et al., 2014; Roselló-Soto, 2019). 
Like in other West African countries, tigernut is grossly underutilized and underexploited in Nigeria. The awareness of its potentials is gradually propping up. Unlike in the European countries where tigernut drink or milk is produced at an industrial scale, its production in Nigeria is mostly at the local level where individuals produce the drink in their homes. Sometimes, one sights vendors producing in open markets where hygienic practices are not observed. One of such is the case with this study at Yenagoa, Nigeria. Each stage of the drink production has a high probability of containing a large number of microorganisms due to the low level of sanitary precautions employed.

With the growing need to increase the production and utilization of locally available food resources, tigernut drink will aid in solving major nutritional and dietary issues by exploiting its nutritional and economic potentials. The study is therefore aimed at determining the bacteriological composition of biofilms of the equipment and utensils used in producing tigernut drink. The results obtained will not only provide a baseline data on the composition of the microbial biofilms but also point out sanitary measures required in the production of the drink.

\section{MATERIALS AND METHODS}

\section{Study Area}

The study was carried out in an open market area located at Arietallin in Swali-Yenagoa, Bayelsa State, Nigeria; latitude $4.9186^{\circ} \mathrm{N}$ and longitude $6.2673^{\circ} \mathrm{E}$. A singular vendor who had her tigernut drink processing unit and selling point was in this open market. The processing unit included a metal grinding machine, plastic collection bowls, sieve, water storage bowls and retail bottles also made of plastic.

\section{Biofilm and Water Sampling}

Sampling was done at various points in the process line: the grinding machine (top and middle), collection bowl 1, collection bowl 2, water storage containers (two in number) and retail bottles (two in number), making a total of 8 (eight) points in the process line (designated $\mathrm{Xa}, \mathrm{Xb}, \mathrm{Ya}$, $\mathrm{Yb}, \mathrm{Za}, \mathrm{Zb}, \mathrm{Pa}$ and $\mathrm{Pb}$ respectively). Triplicate biofilm samples were collected by rubbing gently on surfaces $(2-3 \mathrm{~cm})$ of different areas at each sampling point, using moist and sterile swab sticks (Flach et al., 2014; Cherif-Antar et al., 2016; Weber et al. 2019), to give a total of 24 samples $\left(\mathrm{Xa}_{1,2,3}, \mathrm{Xb}_{1,2,3}, \mathrm{Ya}_{1,2,3}, \mathrm{Yb}_{1,2,3}, \mathrm{Za}_{1,2,3}, \mathrm{Zb}_{1,2,3}, \mathrm{~Pa}_{1,2,3}\right.$ and $\left.\mathrm{Pb}_{1,2,3}\right)$. Water samples (control) used during processing were collected in triplicate into $30 \mathrm{ml}$ sterile bottles. The samples were transported to the laboratory in ice packs and then stored in the refrigerator at $4^{\circ} \mathrm{C}$ before analysis. All analyses were performed within 48 hours of obtaining the samples.

\section{Bacterial Isolation and Enumeration}

Standard procedures were followed in the isolation and enumeration of bacteria. Moist swabs of biofilms from the different sampling points were suspended in $5 \mathrm{ml}$ of sterile normal saline to give stock cultures for each sampling point. A loopful of each stock culture was inoculated in triplicates on growth media: Salmonella-Shigella Agar, MacConkey Agar and Nutrient Agar to check for bacterial growth, which was recorded as "growth" or "no growth". All media were prepared according to the manufacturer's instructions. 
For total heterotrophic bacterial counts, $0.5 \mathrm{ml}$ of stock culture from each sampling point was diluted serially in $4.5 \mathrm{ml}$ sterile normal saline. $0.5 \mathrm{ml}$ of dilution $10^{-3}$ was then inoculated onto nutrient agar plates using the pour plate method. For water, serial dilutions of $1 \mathrm{ml}$ samples were performed in $9 \mathrm{ml}$ normal saline. $0.1 \mathrm{ml}$ of dilution $10^{-3}$ was then inoculated onto nutrient agar. All plates were incubated at $30^{\circ} \mathrm{C}$ for 24 to 48 hours. Resulting colonies were further subcultured and purified on growth medium before identification.

\section{Bacterial Identification and Characterization}

Resulting colonies from the growth media were identified and characterized based on their cultural characteristics, microscopy on Gram's stain and biochemical reactions (catalase, oxidase, citrate, etc.) before grouping into various genera. Standard protocols were employed.

\section{Statistical analyses}

Statistical computations and illustrations were done with Microsoft Excel (version 2013) and SPSS (version 20.0) for Analysis of Variance (ANOVA) and Duncan's Multiple Range (DMR) tests employed in post-hoc analysis of sources of variations.

\section{RESULTS AND DISCUSSION}

Results of the preliminary growth of swab stock cultures at different areas of the sampling points are given in Table 1. All samples indicated growth on nutrient agar but not on Salmonella-Shigella agar and MacConkey agar, because of the selective/differential nature of the latter two. Sampling point Xa, which is the grinder top, harboured no Enterobacteriaceae since no growth occurred on MacConkey agar, while sampling points $\mathrm{Pa}$ and $\mathrm{Pb}$ (retail bottles) showed no growth of Salmonella or Shigella species. Every other sampling point harboured these groups of bacteria.

The total heterotrophic bacterial counts of the sampling points ranged from log $3.28 \pm 0.06$ $\mathrm{cfu} / \mathrm{cm}^{2}$ to $\log 5.18 \pm 0.05 \mathrm{cfu} / \mathrm{cm}^{2}$, and $\log 5.13 \pm 0.07 \mathrm{cfu} / \mathrm{ml}$ for the water sample (Table 2). Sampling point $\mathrm{Xb}$ - the grinders - recorded the highest level of contamination with a statistically significant difference $(\mathrm{P}<0.05)$. The surfaces of food processing equipment and utensils have for long been established as sources of food products contamination by microorganisms. The grinder middle, which had the highest bacterial load, suggests more formation of biofilms and the least level of cleaning/hygiene would have occurred here probably due to its hidden position with restricted accessibility. Sampling point Xa-the grinder top - had the second largest bacterial load. This may be because of it being the entry point of the raw materials (tiger nuts, other additives and water) used for the drink production. The collection bowls ( $\mathrm{Ya} ; \mathrm{Yb})$ and water storage bowls $(\mathrm{Za} ; \mathrm{Zb})$ had close values of bacterial contamination which could have resulted from their exposure to the environment. The retail bottles $(\mathrm{Pa} ; \mathrm{Pb})$ were the least contaminated. This may be because they are usually the most well cleaned and well covered, but the high bacterial load may suggest that they were recycled without proper washing or washed with contaminated water.

The water used for tiger nut drink production had high bacterial load (statistically significant, $\mathrm{P}<0.05$ ). This may be because it was not well treated; it is therefore unfit for consumption as the case is usually with surface and groundwater in Bayelsa State, Nigeria. Reports of high 
heterotrophic bacterial contamination of between $10^{2}-10^{6} \mathrm{cfu} / \mathrm{ml}$ in portable water (both treated and untreated) are not uncommon in this zone (Angaye et al., 2015; Izah and Ineyougha, 2015; Mbah, et al., 2017; Seiyaboh et al., 2017). This bacterial density in the portable water used for the drink production surpassed the World Health Organization/Food and Agricultural Organization permissible limit of $1.0 \times 10^{2} \mathrm{cfu} / \mathrm{ml}$ total heterotrophic bacteria.

Bacteria isolated from the surfaces of the processing unit were Streptococcus spp., Staphylococcus spp., Vibrio spp., Escherichia coli, Shigella spp. and Salmonella spp. Shigella spp. were the most isolated (27.451\%), followed closely by Salmonella spp. (21.568\%) and then E. coli (15.686\%). Streptococcus spp., Staphylococcus spp. and Vibrio spp. were the least isolated with the same frequency of occurrence (11.765\%) (Table 3). Characterization of the microorganisms is shown in Table 4. Several authors have isolated these microorganisms on surfaces of food utensils in Nigeria (Maori and De, 2010; Nwakanma and Chidobi, 2016; Igwe et al., 2020).

Shigella and Salmonella species occurred at all sampling points but were absent on the surfaces of the retail bottles. E coli was present in the water collection bowls and retail bottles while Streptococcus, Staphylococcus and Vibrio were found only in the retail bottles. This suggests that each microorganism could have a preference for a material surface as they differed. Moreso, some surface materials are more likely to form biofilms than others (Garrett et al., 2008). Sampling point $X$ was metal, $Y$ and $Z$ were a thicker form of plastic and $P$, a lighter form of plastic. Four genera of the microorganisms were the most isolated from the retail bottles (39.216\%): Streptococcus spp., Staphylococcus spp., Vibrio spp. and fewer E. coli. Less genera $(25.490 \%)$ occurred on the water storage containers (Shigella, Salmonella and mostly E. coli) while lesser still (17.647\%) were on the grinder and collection bowls (Shigella and Salmonella only). This further suggests that the genera of microbes on the retail bottles were able to attach easily, probably due to the presence of limited but available nutrients, since the bottles are recycled and may not have been properly washed. E. coli was more on the water storage containers as it is a waterborne pathogen as well as an indicator of water pollution. Shigella and Salmonella species were mainly on the mechanical grinders and collection bowls, and would have formed greater amounts of biofilms due to the availability of additional nutrients.

The high microbial load on surfaces of the grinder and the containers reflects the level of hygiene employed in the cleaning of the materials prior to drink production. Flach et al. (2014) reported counts of up to $10^{6} \mathrm{cfu} / \mathrm{cm}^{2}$ on metal surfaces of a dairy production plant as indicative of poor cleaning of equipment and strong evidence of the presence of microbial biofilms. Microbial counts of $\log 10 \mathrm{cfu} / \mathrm{cm}^{2}$ to $\log 10^{6}$ have long been documented as contamination of equipment in dairy processing plants (Gibson et al., 1999; Weber et al., 2019). Counts of log $10^{3}-10^{5} \mathrm{cfu} / \mathrm{cm}^{2}$ were obtained in this study. The main sources of milk and milk-related products contamination are attributed to improper cleaning and disinfection of equipment (Cherif-Antar et al., 2016). Tiger nut extract is milky and can be referred to as a milky drink.

Diverse microbial genera isolated from the surfaces of dairy processing equipment include: Enterococcus, Bacillus, Staphylococcus, Escherichia, Klebsiella, Acinetobacter, Serratia, Enterobacter, Pseudomonas, Proteus, Lactobacillus, Listeria, Micrococcus and Streptococcus. The occurrence of Vibrio, Shigella and Salmonella species in this study further indicates the very poor sanitary condition of the process line. Sources of food contamination are usually water, raw materials, equipment, insects, rodents and food handlers themselves. Biofilms are 
considered now as the major source of food contamination as they can persist on the process line and cause reinfection, even after cleaning and disinfection.

Removing surface-attached cells and established biofilms pose a great challenge to the dairy industry. To avoid surface contamination, adhesion and subsequent biofilm formation, adequate prevention and control strategies must be employed. Proper and strict hygienic measures must be followed, and the environment for drink production must be conducive and enclosed, as the reverse was the case in this study. Sanitation enforcement and regulation agencies must ensure proper compliance to standards. The equipment used in processing should be designed in such a way that crevices, dead ends, corners, etc. which are areas for biofilm accumulation would be easily accessible in terms of cleaning. The material used for equipment manufacture should be cleaned with ease using biocides or detergents. Although the aim of this research was not to ascertain the microbial load of the tigernut drink, information gathered revealed that the drink is usually sold immediately after preparation without pasteurization. This further places consumers at risk of infection as the water utilized has high bacterial load. Drink pasteurization is therefore recommended.

\section{CONCLUSION}

Tiger nut drink is a well-loved drink gaining great acceptability in Nigeria because it is natural, cheap and highly nutritious. Due to its gaining popularity, attention should be given to its production process. This research has uncovered the low level of hygiene employed during the drink production from a singular producer and vendor of the drink located in an open market. There are many other vendors of this drink who carry out the production process in their homes, where they cannot be monitored so as to ascertain the level of hygiene practiced. A wellequipped, organised and modern production plant/industry where standard practices are followed from harvesting, transportation and processing to bottling of tigernut drink, with compliance of clean-in-place (CIP) methods would be a welcome idea in Nigeria.

\section{REFERENCES}

Abdallah, M., Benoliel, C., Drider, D., Dhulster, P. and Chihib, N-E. (2014). Biofilm formation and persistence on abiotic surfaces in the context of food and medical environments. Archives of Microbiology, 196: 453 - 472. doi 10.1007/s00203-0140983-1

Agbaje, R. B., Oyetayo, O. V., and Ojokoh, A. O. (2015). Assessment of the microbial and physico-chemical composition of tigernut subjected to different fermentation methods. Pakistan Journal of Nutrition, 14: 742 - 748.

Angaye, T. C. N., Ohimain, E. I. and Mieyepa, C. E. (2015). The potability of groundwater in Ayeh-Kumi, P. F., Tetteh-Quarcoo, P. B., Duedu, K. O., Obeng, A. S., Addo-Osafo, K., Mortu, S. and Asmah, R. H. (2014). A survey of pathogens associated with Cyperus esculentus L (tiger nuts) tubers sold in a Ghanaian city. BMC Research Notes, 7: 343.

Balewu, M. A. and Balewu, K. Y. (2007). Comparative physico-chemical evaluation of tigernut, soybean and coconut milk sources. International Journal of Agriculture and Biology, 9: 785 - 787. 
Bayelsa State, Central Niger Delta Nigeria: A Review. Journal of Environmental Treatment Techniques, 3(2): $134-142$.

Biofilms: an emergent form of bacterial life. Nature Reviews Microbiology, 14: 563 - 575. doi: $10.1038 /$ nrmicro.2016.94

Brooks, J. D. and Flint, S. H. (2008). Biofilms in the food industry: problems and potential solutions. International Journal of Food Science and Technology, 43: $2163-2176$.

Cherif-Antar, A., Moussa-Boudjemâa, B., Didouh, N., Medjahdi, K., Mayo, B. and Flórez, A. B. (2016). Dairy Science and Technology, 96: 27 - 38. doi 10.1007/s13594-0150235-4

Chmielewski, R. A. N. and Frank, J. F. (2003). Biofilm formation and control in food processing facilities. Comprehensive Reviews in Food Science and Food Safety, 2(1): $22-32$.

Chukwu, M. O., Ibiam O. F. A. and Okoi, A. (2013). Studies on the fungi and phytochemical and proximate composition of dry and fresh tiger nuts (Cyperus esculentus L.). International Research Journal of Biotechnology, 4(1): 11 - 14.

Colagiorgi, A., Bruini, I., Di Ciccio, P. A., Zanardi, E., Ghidini, S. and Ianieri, A. (2017). Listeria monocytogenes biofilms in the wonderland of food industry. Pathogens, 6 (30): 41. doi: 10.3390/pathogens6030041.

Flach, J., Grzybowski, V., Toniazzo, G. and Corção, G. (2014). Adhesion and production of degrading enzymes by bacteria isolated from biofilms in raw milk cooling tanks. Food Science and Technology, Campinas, 34(3): 571 - 576.

Flemming, H. C., Wingender, J., Szewzyk, U., Steinberg, P., Rice, S. A., and Kjelleberg, S. (2016).

Galié, S., García-Gutiérrez, C., Miguélez, E. M., Villar, C. J. and Lombó, F. (2018). Biofilms in the Food Industry: Health Aspects and Control Methods. Frontiers in Microbiology, 9: 898. doi: 10.3389/fmicb.2018.00898

Gambo, A. and Da'u, A. (2014). Tiger nut (Cyperus esculentus): Composition, products, uses and health benefits - a review. Bayero Journal of Pure and Applied Sciences, 7(1): 56 61.

Garrett, T. R., Bhakoo, M. and Zhang, Z. (2008). Bacterial adhesion and biofilms on surfaces. Progress in Natural Science, 18: 1049 - 1056.

Gibson, H., Taylor, J. H., Hall, K. E. and Holah, J. T. (1999). Effectiveness of cleaning techniques used in the food industry in terms of the removal of bacterial biofilms. Journal of Applied Microbiology, 87: $41-48$.

Hubert, D. N., Daniel, N. A. T and Yaw, A. (2011). Assessment of microbiological safety of tigernuts (Cyperus esculentus. L) in the cape coast metropolis of Ghana. Archives of Applied Science Research, 3(6): 257 - 262.

Igwe, G. O., Afunwa, R., Ezebialu, C, and Unachukwu, M. N. (2020). Bacteriological examination of utensils and hands of food vendors in a university cafeteria in Enugu, Nigeria. Journal of Biology and Life Science, 10(1) doi: $10.5296 / \mathrm{jbls.v10i1.14267}$

Izah, S. C. and Ineyougha, E. R. (2015). A review of the microbial quality of potable water sources in Nigeria. Journal of Advances in Biological and Basic Research, 1(1): 12 19.

Karunakaran, E., Mukherjee, J., Ramalingam, B. and Biggs, C. A. (2011). "Biofilmology": a multidisciplinary review of the study of microbial biofilms. Applied Microbiology and Biotechnology, 90: 1869 - 1881. 
Maori, L. and De, N. (2010). Bacterial contamination of crockery and cutlery within the kiosks' restaurants of the Federal University of Technology, Yola. African Journal of Microbiology Research, 4 (3): 147 - 153.

Marchand, S., De Block, J., De Jonghe, V., Coorevits, A., Heyndrickx, M. and Herman, L. (2012).

Marouani-Gadri, N., Firmesse, O., Chassaing, D., Sandris-Nielsen, D., Arneborg, N. andCarpentier, B. (2010). Potential of Escherichia coli O157:H7 to persist and form viable but not-culturable cells on a food-contact surface subjected to cycles of soiling and chemical treatment. International Journal of Food Microbiology, 144(1): 96 - 103.

Mbah, E. I., Ibe, S. N. and Abu, G. O. (2017). Water quality assessment of the freshwater ecosystem at communities' points-of-use in Yenagoa Metropolis of Bayelsa State, Nigeria. Research Journal of Pure Science and Technology, 1(1): 15 - 22.

Milk production and processing environments; influence on milk quality and safety. Comprehensive Reviews in Food Science and Food Safety, 11:133 - 147.

Nwakanma, C. and Chidobi, C. C. (2016). The study of bacteria occurrence in kitchen utensils used in restaurants in Godfrey Okoye University. European Journal of Biomedical and Pharmaceutical Sciences, 3(9): 143 - 146.

Onovo, J. C. and Ogaraku, A. O. (2007). Studies on some microorganisms associated with exposed tigernut (Cyperus esculentus L.) milk. Journal of Biological Sciences, 7 (8): $1548-1550$.

Remize, F. (2019). Review: Nutritional and microbiological quality of tiger nut tubers (Cyperus esculentus), derived plant-based and lactic fermented beverages. Fermentation, 5: 3. doi:10.3390/fermentation5010003

Roselló-Soto, E., Garcia, C., Fessard, A., Barba, F. J., Munekata, P. E. S., Lorenzo, J. M. and

Sagoo, S. K., Little, C. L. and Mitchell, R. T. (2001). The microbiological examination of ready-to-eat organic vegetables from retail establishments in the United Kindom. Letters in Applied Microbiology. 33(6): 434 - 439. doi: 10.1046/j.1472765X.2001.01026.x

Satpathy, S., Sen, S. K., Pattanaik, S and Raut, S. (2016). Review on bacterial biofilm: A universal cause of contamination. Biocatalysis and Agricultural Biotechnology 7, 56 66.

Seiyaboh, E. I., Izah, S. C. and Bokolo, J. E. (2017). Bacteriological Quality of Water from River Nun at Amassoma Axises, Niger Delta, Nigeria. ASIO Journal of Microbiology, Food Science and Biotechnological Innovations (ASIO-JMFSBI), 3(1): 22 - 26. doi: 10.2016-53692176.

Shakibaie, R. S. (2018). Bacterial biofilm and its clinical implications. Annals of Microbiology and Research, 2(1): 45 - 50.

Suleiman, M. S., Olajide, J. E., Omale, J. A., Abbah, O. C. and Ejembi, D. O. (2018). Proximate composition, mineral and some vitamin contents of tigernut (Cyperus esculentus). Clinical Investigation (London,) 8(4): $161-165$.

Tilahun, A., Haddis, S., Teshale, A. and Hadush, T. (2016). Review on biofilm and microbial adhesion. International Journal of Microbiological Research, 7 (3): 63 - 73. doi: 10.5829/idosi.ijmr.2016.63.73

Van Houdt, R. and Michiels, C. W. (2010). Biofilm formation and the food industry, a focus on the bacterial outer surface. Journal of Applied Microbiology, 109: 1117 - 1131.

Vert, M., Doi, Y., Hellwich, K., Hess, M., Hodge, P., Kubisa, P., Rinaudo, M. and Schué, F. (2012). "Terminology for biorelated polymers and applications (IUPAC Recommendations 2012)". Pure and Applied Chemistry. 84 (2): 377 - 410. 
African Journal of Environment and Natural Science Research

ISSN: 2689-9434

Volume 4, Issue 2, 2021 (pp. 59-70)

www.abjournals.org

Weber, M., Liedtke, J., Plattes, S. and Lipski, A. (2019). Bacterial community composition of biofilms in milking machines of two dairy farms assessed by a combination of culturedependent and -independent methods. PLoS ONE, 14(9): e0222238.

https://doi.org/10.1371/journal. pone.0222238 


\section{APPENDIX}

Table 1: Preliminary culture of swab suspensions on growth media

\begin{tabular}{|c|c|c|c|c|c|c|c|c|c|}
\hline \multirow{3}{*}{$\begin{array}{l}\text { Sampling } \\
\text { Point }\end{array}$} & \multicolumn{9}{|c|}{ Growth Medium } \\
\hline & \multicolumn{3}{|c|}{ SSA } & \multicolumn{3}{|c|}{ MA } & \multicolumn{3}{|c|}{ NA } \\
\hline & 1 & 2 & 3 & 1 & 2 & 3 & 1 & 2 & 3 \\
\hline $\mathbf{X a}$ & + & - & + & - & - & - & + & + & + \\
\hline $\mathbf{X b}$ & + & + & + & + & + & - & + & + & + \\
\hline Ya & + & - & + & + & - & - & + & + & + \\
\hline $\mathbf{Y b}$ & + & + & + & + & - & + & + & + & + \\
\hline $\mathbf{Z a}$ & + & - & - & + & - & + & + & + & + \\
\hline $\mathbf{Z b}$ & + & + & + & + & + & + & + & + & + \\
\hline $\mathbf{P a}$ & - & - & - & + & - & - & + & + & + \\
\hline $\mathbf{P b}$ & - & - & - & + & - & - & + & + & + \\
\hline
\end{tabular}

Key: SSA: Salmonella-Shigella Agar; MA: MacConkey Agar; NA: Nutrient Agar; Xa: Grinder top; Xb: Grinder middle; Ya: Collection bowl 1; Yb: Collection bowl 2; Za: Water storage container 1; Zb: Water storage container 2; Pa: Retail bottle 1; Pb: Retail bottle 2.

+: growth; -: no growth.

Table 2: Total heterotrophic bacterial counts of the sampling points and water

\begin{tabular}{|l|l|}
\hline Sample & THBC \\
\hline Sampling point $\mathrm{Xa}$ & $4.98 \pm 0.05 \mathrm{~d}$ \\
\hline Sampling point $\mathrm{Xb}$ & $5.18 \pm 0.05 \mathrm{~d}$ \\
\hline Sampling point $\mathrm{Ya}$ & $3.60 \pm 0.12 \mathrm{c}$ \\
\hline Sampling point $\mathrm{Yb}$ & $3.51 \pm 0.20 \mathrm{bc}$ \\
\hline Sampling point $\mathrm{Za}$ & $3.43 \pm 0.24 \mathrm{abc}$ \\
\hline Sampling point $\mathrm{Zb}$ & $3.60 \pm 0.05 \mathrm{c}$ \\
\hline Sampling point $\mathrm{Pa}$ & $3.37 \pm 0.01 \mathrm{ab}$ \\
\hline Sampling point $\mathrm{Pb}$ & $3.28 \pm 0.06 \mathrm{a}$ \\
\hline Water & $5.13 \pm 0.07 \mathrm{~d}$ \\
\hline
\end{tabular}

Each result is the mean of triplicate values. Values with different alphabets are significantly different at $\mathrm{P}<0.05$ with post hoc analysis using Duncan's Multiple Range.

Key: Xa: Grinder top; Xb: Grinder middle; Ya: Collection bowl 1; Yb: Collection bowl 2; Za: Water storage container 1; Zb: Water storage container 2; Pa: Retail bottle 1; Pb: Retail bottle 2

THB: Total Heterotrophic Bacteria Count 
Table 3: Occurrence (\%) of bacterial isolates at the various sampling points

\begin{tabular}{|c|c|c|c|c|c|c|c|c|c|c|c|c|c|c|c|c|c|c|c|c|c|c|c|c|c|}
\hline \multirow[t]{3}{*}{ Bacteria Isolate } & \multicolumn{24}{|c|}{ Sampling Points } & \multirow[t]{3}{*}{ Total (\%) } \\
\hline & \multicolumn{3}{|c|}{$\mathrm{Xa}$} & \multicolumn{3}{|c|}{$\mathrm{Xb}$} & \multicolumn{3}{|c|}{$\mathrm{Ya}$} & \multicolumn{3}{|c|}{$\mathrm{Yb}$} & \multicolumn{3}{|c|}{$\mathrm{Za}$} & \multicolumn{3}{|c|}{$\mathrm{Zb}$} & \multicolumn{3}{|c|}{$\mathrm{Pa}$} & \multicolumn{3}{|c|}{$\mathrm{Pb}$} & \\
\hline & 1 & 2 & 3 & 1 & 2 & 3 & 1 & 2 & 3 & 1 & 2 & 3 & 1 & 2 & 3 & 1 & 2 & 3 & 1 & 2 & 3 & 1 & 2 & 3 & \\
\hline Streptococcus spp. & - & - & - & - & - & - & - & - & - & - & - & - & - & - & - & - & - & - & + & + & + & + & + & + & $6(11.765)$ \\
\hline Staphylococcus spp. & - & - & - & - & - & - & - & - & - & - & - & - & - & - & - & - & - & - & + & + & + & + & + & + & $6(11.765)$ \\
\hline Vibrio spp. & - & - & - & - & - & - & - & - & - & - & - & - & - & - & - & - & - & - & + & + & + & + & + & + & $6(11.765)$ \\
\hline Escherichia coli & - & - & - & - & - & - & - & - & - & - & - & - & + & + & + & + & + & + & - & + & - & - & - & + & $8(15.686)$ \\
\hline Shigella spp. & + & + & - & + & + & + & + & + & - & + & + & + & - & - & + & + & + & + & - & - & - & - & - & - & $14(27.451)$ \\
\hline Salmonella spp. & - & + & + & + & - & + & + & + & + & - & + & - & - & - & - & + & + & + & - & - & - & - & - & - & $11(21.568)$ \\
\hline Total (\%) & & & $(17$ & & & & & & & & & & & & 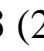 & .49 & & & & & & & & & $51(100)$ \\
\hline
\end{tabular}


Table 4: Identification and characterization of bacterial isolates

\begin{tabular}{|c|c|c|c|c|c|c|c|}
\hline \multirow[t]{2}{*}{ Bacterial Isolate } & \multirow[t]{2}{*}{ Morphology and Cultural Characteristics } & \multicolumn{6}{|c|}{ Biochemical Reactions } \\
\hline & & Catalase & Oxidase & Citrate & Coagulase & Sucrose & Glucose \\
\hline $\begin{array}{l}\text { Streptococcus } \\
\text { spp. }\end{array}$ & $\begin{array}{l}\text { Gram positive diplococci. Tiny cream-coloured colonies } \\
\text { on nutrient agar. }\end{array}$ & - & - & + & - & + & + \\
\hline $\begin{array}{l}\text { Staphylococcus } \\
\text { spp. }\end{array}$ & $\begin{array}{l}\text { Gram positive cocci in clumps, grape-like clusters. } \\
\text { Cream, smooth, opaque colonies on nutrient agar. }\end{array}$ & + & - & + & - & + & + \\
\hline Vibrio spp. & $\begin{array}{l}\text { Gram negative short rods, grey colonies on nutrient agar, } \\
\text { colourless and tiny colonies on MacConkey agar (non- } \\
\text { lactose fermenter). }\end{array}$ & + & + & + & - & + & + \\
\hline Escherichia coli & $\begin{array}{l}\text { Gram negative rods, large, greyish white, smooth and } \\
\text { opaque colonies on nutrient agar. Pink and large colonies } \\
\text { on MacConkey agar (lactose fermenter). }\end{array}$ & + & - & - & - & + & + \\
\hline Shigella spp. & $\begin{array}{l}\text { Short, gram negative rods. Smooth, greyish white colonies } \\
\text { on nutrient agar, pale colonies on MacConkey agar (non- } \\
\text { lactose fermenter). Transparent colonies on Salmonella- } \\
\text { Shigella agar. }\end{array}$ & + & - & - & - & - & + \\
\hline Salmonella spp. & $\begin{array}{l}\text { Gram negative rods. Smooth, greyish white colonies on } \\
\text { nutrient agar, pale colonies on MacConkey agar (non- } \\
\text { lactose fermenter), transparent colonies with black centres } \\
\text { on Salmonella-Shigella agar. }\end{array}$ & + & - & + & - & - & + \\
\hline
\end{tabular}

